\title{
COMPARATIVE EVALUATION OF REPRODUCTIVE PERFORMANCE AND SOME EGG QUALITY PARAMETERS OF BLACK AND WHITE SKINNED SNAILS
}

\author{
B. OKON, L. A. IBOM, M. E. WILLIAMS AND I. E. AKPAKPAN
}

(Received 4, September 2008; Revision Accepted 18, May 2009)

\begin{abstract}
One hundred sexually matured snails, fifty each of the black skinned and white skinned ectotypes were used in the evaluation of reproductive performance and egg quality traits in a study that lasted for eighty-four days. The reproductive performance traits measured included clutch size (number of eggs laid per clutch), incubation period (days) of eggs, percent hatchability, and percent mortality and survivability, while the egg quality traits evaluated included egg weight and length. Results obtained showed significant differences at different levels among parameters measured in the two ectotypes of snails studied. The results of reproductive traits showed that mean clutch sizes were 5 and 4 for black skinned and white skinned ectotypes respectively. Mean incubation periods were 25.8 days for the black skinned ectotype and 22 days for the white skinned ectotype. The values for mean percent hatchability were $26.8 \%$ and $22.8 \%$ for the black skinned and white skinned ectotypes respectively. Mean survivability values were $22.8 \%$ for black skinned ectotype and $20 \%$ for the white skinned ecotype. The mean egg quality parameters were 2.7 $\mathrm{g}$ and $2.4 \mathrm{~g}$, weight for black skinned and white skinned ectotypes respectively. The mean egg lengths were $4.6 \mathrm{~mm}$ and $4.2 \mathrm{~mm}$ for black skinned and white skinned ectotypes respectively. Among the measured parameters, clutch size and egg length had very high significant difference $(P<0.001)$, incubation period had high significant difference $(P<0.01)$ while percent hatchability, survivability and egg weight were significantly different at $(P<0.05)$ level of probability. Strong positive correlation was observed for hatchability and survivability in both ectotypes. All other trait pairs evaluated except percent hatchability : Clutch size in the white ectotype were positively correlated. Strong positive correlations imply that selection for one trait will lead to improvement in the other.
\end{abstract}

KEY WORDS: Reproductive performance, Egg quality, Black skinned, White skinned, Snail.

\section{INTRODUCTION}

Protein intake is one of the essential elements of nutrition for growth and normal functioning of the body. The supply of animal protein in Nigeria is inadequate as the country relies on the traditional animal husbandry system characterized by low inputs, high cost of feed and low productivity of local animal breeds for the supply of this commodity. The World Bank (2001) reported that animal protein constitutes only about $17 \%$ of the total protein consumption in the average Nigerian diet, compared to $60 \%$ in the United Kingdom, $67 \%$ in Denmark, 68 \% in New Zealand and $71 \%$ in the United States of America. Esonu (2001) also stated that the level of animal protein intake in the developing countries, including Nigeria represents about one-tenth of the level of intake in the advanced countries.

There is the need to look for cheaper and safe ways of getting animal protein to complement the supply from conventional and regular sources of animal protein. One of such ways is by the domestication of land snails which Nigeria is richly endowed with. Snail meat is high in protein, iron, calcium and phosphorus, but low in sodium, fat and cholesterol, and contains almost all the amino acids needed by man (Ajayi et al., 1978, Awesu,
1980, Adeyeye, 1996, Akinnusi, 2002 and Ejidike, 2002). Adeyeye (1996) further stated that the African giant snail (Archachatina marginata) is considered as a delicacy in Nigeria and it commands high demand in the market.

The African giant snail has been classified on the basis of skin (foot) colour into black and white ectotypes by Amusan and Omidiji (1998), Akinnusi (2004) and Omole et al. (2007). Ibom et al. (2008) opined that these ectotypes may differ in many production characteristics. There is the need therefore to investigate the reproductive performance (clutch size, incubation period, percent hatchability and percent mortality and survivability of snailets) and some egg quality parameters (mean egg weight and length) of these ectotypes to provide baseline information for future studies, especially as the white skinned ectotype had not been subjected to much scientific investigation.

\section{MATERIALS AND METHODS}

This research was conducted at the Botanical garden, University of Calabar, Calabar. Calabar is

B. Okon, Department of Animal Sciences, University of Calabar Calabar-Nigeria

L. A. Ibom, Department of Animal Sciences, Cross River University of Technology, Obubra Campus-Nigeria

M. E. Williams, Dept of Animal Production, Akwa Ibom State College of Agric.. P.M.B1001, Abak, Oruk Anam Local

Government Area, Akwa Ibom State. Nigeria

I. E. Akpakpan, Department of Animal Sciences, University of Calabar Calabar-Nigeria 
$4^{0} 58^{\prime} \mathrm{N}$ and longitudes $8^{0} 17^{\prime} \mathrm{E}$ of the equator with an annual temperature and rainfall ranges of $25^{\circ}-30^{\circ} \mathrm{C}$ and $1260-1280 \mathrm{~mm}$ respectively. The Botanical garden provided a micro-environment similar to the natural habitat of snails as it is planted with trees like citrus, mango, almond, pawpaw, plantain and banana, and crops like cassava, yam, cocoyam and maize. These trees and crops provided shade that protected the hutches from direct sunlight and heavy rainfall.

One hundred sexually matured snails, fifty each of the black skinned and white skinned ectotypes purchased from a local market were used for the study. The skin (foot) colour, black and white of these ectotypes constituted treatments. Each ectotype was randomly allocated into five treatments of five replicates, with two snails to a replicate. The replicates were managed in wooden cage compartments measuring $0.50 \times 0.50 \mathrm{sq} . \mathrm{cm}$ by $30 \mathrm{~cm}$ deep. The cage compartments were covered with mosquito net reinforced with wire mesh. The stocking density of two snails to a cage compartment was to ensure that eggs obtained from them were a result of the mating between these two.

The snails were given feed ad libitum with water always throughout the twelve weeks this study lasted. They were fed fresh Carica papaya leaves as recommended by Awesu (1980) and Imevbore (1990), in the morning and concentrate in the evening. The concentrate feed was formulated to contain $23.04 \%$ CP and $2995 \mathrm{Kcal} / \mathrm{kgME}$ with the following ingredients; soyabean meal $(22 \%)$, cassava flour $(28 \%)$, bone meal (20\%) and oyster shell (30\%).

Measured parameters included reproductive performance traits (clutch size, incubation period (days), percent hatchability and percent mortality and survivability of snailets) and some egg quality parameters (mean egg weight and length). Data collected were analyzed using t-test statistical tool as modified by Madukwe (2004). Correlations among traits were determined according to methods outlined by Falconer (1989) and Ibe (1998).

\section{RESULTS AND DISCUSSION}

Results of the reproductive performance traits for the two ectotypes are presented in Table 1, with mean clutch sizes of 5 (range $4-6$ ) and 4 (range $3-5$ ) for black skinned and white skinned ectotypes respectively. The mean clutch values obtained in this study were highly significant $(P<0.001)$ between the two ectotypes studied (Table 1 ). The significant values showed that the black skinned ectotype had larger clutch size and is therefore more prolific than the white skinned ectotype. The large clutch size of the black skinned ectotype is in agreement with lbom et al. (2008) who reported that the black skinned ectotype is more prolific than the white skinned ectotype. The clutch size values obtained in this study were lower than the 7.80 and 5.23 reported by lbom et al. (2008) for black skinned and white skinned ecotypes respectively. The mean clutch sizes of this study (Table 1) fall within the range of $1-6$ reported by Ubua (2004) for $A$. marginata. The low mean clutch sizes obtained might be due to the concentrate feed used, as it appeared paltry without a diluent.
Table 1 shows that the mean incubation periods were 25.8 days (range 20 - 30 days) for the black skinned ectotype and 22 days (range 18 - 26 days) for the white skinned ectotype. The mean incubation values obtained in this study were significantly different $(P<0.01)$ between the two ectotypes. The variations in incubation periods between the two ectotypes confirmed the assertion of Ogogo (2004) that snails incubation period vary with species. The incubation periods obtained in this study agree with the works of Cobbinah (1993) and Stievenant (1996) who reported $2-3$ weeks and $2-4$ weeks respectively.

The mean percent hatchability obtained was $26.8 \%$ (range $20-42 \%$ ) for black skinned ectotype and $22.8 \%$ (range $16-28 \%$ ) for white skinned ectotype. These mean percent hatchability values differed significantly $(P<0.05)$ between the ectotypes. The significant difference in mean percent hatchability between the two ectotypes indicates that the black skinned ecotype had a higher percent hatchability than the white skinned ectotype (Table 1). It can be inferred that hatchability is positively correlated to clutch size in the black skinned ectotype while it is negatively correlated in the white skinned ectotype (Table 2). The mean percent hatchability values obtained in this study falls within the range $(0-100 \%)$ reported by Ogogo (1989) for snails in the tropics.

Mean percent survivability values of $22.8 \%$ (range $16-34 \%$ ) and $20 \%$ (range16 - $24 \%$ ) were obtained for black skinned and white skinned ectotypes respectively. The mean percent survivability of the black skinned ectotype correlated positively with the clutch size, while there was no correlation in the white skinned ectotype. The percent survival values obtained in this study in both ectotypes were lower than values of $70 \%$ and $100 \%$ reported by Adegbaju (2000) and Fapohunda et al. (2007) respectively. These differences may be due to the concentrate feed given and the prevailing environmental conditions (temperature, relative humidity, rain fall, day light and length).

The results of egg quality showed that mean egg weights were $2.7 \mathrm{~g}$ (range $2.5-2.9 \mathrm{~g}$ ) and $2.4 \mathrm{~g}$ (range $2.3-2.5 \mathrm{~g}$ ) for black skinned and white skinned ectotypes respectively. The mean egg weights obtained in this study were significantly different $(P<0.05)$ between the two ectotypes. The results revealed that the black skinned ectotype had larger eggs than the white skinned ectotype and agreed with the findings of Ibom et al. (2008). However, the values obtained were higher than the values of $1.80 \mathrm{~g}$ and $1.05 \mathrm{~g}$ for black skinned and white skinned ectotypes respectively reported by Ibom et al. (2008). The mean egg weight value of the black skinned ectotype was within the range of $2.5-4.6$ $g$ reported by Ogogo (2002) A. marginata. However, the mean egg weight value for the white skinned ectotype was lower than the lower limit of the egg weight range reported by the same author.

The mean egg length values obtained in this study were $4.6 \mathrm{~mm}$ (range $4.6-4.7 \mathrm{~mm}$ ) and $4.2 \mathrm{~mm}$ (range $4.0-4.2 \mathrm{~mm}$ ) for black skinned and white skinned ectotypes respectively. The mean egg lengths obtained in this study were highly significant $(P<0.001)$ between the two ectotypes studied. The black skinned ectotype mean egg length of this study was within the range of $4.5-5.5 \mathrm{~mm}$ reported by Stievenant (1996) 
while that of the white skinned ectotype was relatively lower.

Table 2 shows the degree of correlation between traits among the ectotypes (black skinned and white skinned) of snails studied. As shown, except for percent hatchability: clutch size in the white skinned ectotype, all other pairs of traits evaluated exhibited positive correlation. The results of traits correlation obtained in this study agree with the positions of Falconer (1989) and Ehiobu and Kyado (2000) that correlation can be high or low, positive or negative and/or no correlation at all between traits. Positive correlation could suggest that the pairs of traits have direct relationship or they are controlled by the same genes and in the same direction. Conversely, negative correlation could indicate that the same genes affect the pair of traits in opposite direction. The impact of genes to influence traits positively and/or negatively corroborates the assertion of Ibom (2009). For traits with strong positive correlation, selection for one trait will lead to improvement in the other.

\section{CONCLUSION}

The results of this study revealed that the black skinned ectotype performed better than the white skinned ectotype in both the reproductive and egg quality traits measured. However, both ectotypes are capable of improving the animal protein intake of the populace; as they are relatively cheaper than the conventional sources of animal protein during the rainy season. Sustainable snail production in captivity is therefore recommended for all year round supply of cheap snail meat.

Table 1: Reproductive and egg quality traits of black skinned and white skinned snails (Archachatina marginata).

\begin{tabular}{lccc}
\hline Parameter & \multicolumn{2}{c}{ Mean values/Range } & Level of \\
\cline { 2 - 3 } & BS & WS & Significance \\
\hline Clutch size & $5(4-6)$ & $4(3-5)$ & $P<0.001$ \\
Incubation period (days) & $25.8(20-30)$ & $22(18-26)$ & $P<0.01$ \\
Hatchability (\%) & $26.8(20-42)$ & $22.8(16-28)$ & $P<0.05$ \\
Survivability (\%) & $22.8(16-34)$ & $20(16-24)$ & $P<0.05$ \\
Egg weight (g) & $2.7(2.6-2.9)$ & $2.4(2.3-2.5)$ & $P<0.05$ \\
Egg length (mm) & $4.6(4.6-4.7)$ & $4.2(4.0-4.2)$ & $P<0.001$
\end{tabular}

BS = Black Skinned ectotype, WS = White Skinned ectotype.

Table 2: Correlation of reproductive traits evaluated on black skinned and white skinned nails (Archachatina marginata).

\begin{tabular}{llc} 
Traits & BS & WS \\
\hline Percentage hatchability: Clutch size & $0.46^{*}$ & $-0.13^{\mathrm{NS}}$ \\
Percentage survivability: Clutch size & $0.23^{\mathrm{NS}}$ & $0.00^{\mathrm{NS}}$ \\
Percentage hatchability: Percentage survivability & $0.98^{* *}$ & $0.99^{* *}$ \\
BS = Black Skinned snail, WS = White Skinned snail. & & \\
\hline
\end{tabular}

${ }^{*}=(\mathrm{P}<0.05),{ }^{* *}=(\mathrm{P}<0.001), \mathrm{NS}=\mathrm{P}>0.05$ (Non-significant)

\section{REFERENCES}

Adegbaju, S. W., 2000. A Guide to a Successful Poultry and Snailery Business. Agrocare Series. Pp. $22-29$

Adesope, M. O., 2000. Attitudes of household in a Niger Delta Zone towards snail meat consumption. In: Ukachukwu, S. N. et al. (eds.). Animal production in the new millennium: challenges and options. Zaria: NSAP Secretariat.

Adeyeye, E. I., 1996. Waste yield, proximate and mineral composition of three different types of land snail found in Nigeria. Int. J. Food Sci. and Nutr. 47(2): 111 - 116.
Ajayi, S.S., Tewe, O. O., Moriarty, C. and Awesu, M. O., 1978. Observations on the biological and nutritive value of the African giant snail (Archachatina marginata). East African Wildlife J. 16:85 - 95.

Akinnusi, O., 2002. Introduction to Snails and Snail Farming. Abeokuta, Nigeria. Triolas Exquisite Ventures.

Akinnusi, O., 2004. Introduction to Snails and Snail Farming. $2^{\text {nd }}$ ed. Abeokuta, Nigeria. Triolas Exquisite Ventures.

Amusan, J. A. and Omidiji, M. O., 1998. Edible Land Snail. A Technical Guide to Snail Farming in the Tropics. Ibadan. Variety Printers Limited. 
Awesu, M. O., 1980. The biology and Management of the African Giant Land Snail (A. marginata). M. Phil. Thesis. University of Ibadan. (Unpublished).

Cobbinah, J. R., 1993. Snail Farming in West Africa. A Practical Guide. U.K. Sayee Publishing. CTA Publication.

Ehiobu, N. G. and Kyado, J. A., 2000. Heritability, Repeatability and Genetic correlation of Swine. Proceedings of the $25^{\text {th }}$ Annual Conference of Nigerian Society for Animal Production (NSAP). March 19 - 22, 2000. Umudike, Nigeria. Pp. 260 $-261$.

Ejidike, B. N., 2002. Snail Rearing practices in Southern Nigeria. Proc. $27^{\text {th }}$ Ann. Conf., Nig. Soc. for Anim. Prod. (NSAP). March $17-21,2002$. Akure, Nigeria. Pp. 307 - 308.

Esonu, B. O., 2001. Comparative Evaluation of Raw and Urea/Toasted Velvet Bean (Mucuna pruriens) for Broiler Chicks. Nig. J. Anim. Prod. 28(1): 40 -44 .

Falconer, D. S., 1989. Introduction to Quantitative Genetics. $3^{\text {rd }}$ ed. Burat Mill, England. Longman Group Limited. Pp. $162-169$.

Fapohunda, J. B. Omole, A. J. Obi, O. O. and Adebowale, E. A., 2007. Nutritional value of chicken offal as a replacement for local fish meal in growing snail. Proc. $32^{\text {nd }}$ Ann. Conf., Nig. Soc. for Anim. Prod. (NSAP). March 18 - 21, 2007. Calabar, Nigeria. Pp. $363-364$.

Ibe, S. N., 1998. An Introduction to Genetics and Animal Breeding. Ikeja, Nigeria. Longman Nigeria Plc.

Ibom, L. A., 2009. Variations in reproductive and growth performance traits of white skinned $\mathrm{x}$ black skinned African giant snails hatchlings [Archachatina marginata (Swainson)] in Obubra, Nigeria. Ph.D. Dissertation. Department of Animal Science, University of Calabar, Calabar. (Unpublished).

Ibom, L. A., Okon, B. and Essien, A., 2008. Morphometric analysis of eggs laid by two ectotypes of Archachatina marginata (Swainson) raised in captivity. Proc. $33^{\text {rd }}$ Ann. Conf., Nig Soc. for Anim. Prod. (NSAP). March $16-20,2008$. Olabisi Onabanjo University, Ago-Iwoye, Ogun State, Nigeria. Pp. $28-30$.
Imevbore, E. A., 1990. Management Techniques in Rearing African Giant Land Snail, (Archachatina marginata). Ph.D. Thesis. University of Ibadan. (Unpublished).

Madukwe, M. C., 2004. Multivariate Analysis for Agricultural Extension Research. In (T. A. Olowu eds.) Research Methods in Agricultural Extension. Agricultural Extension Society of Nigeria. (AESON). C/o Agricultural and Rural Management Training Institute (ARMTI). Ilorin. Pp. $206-236$.

Ogogo, A. U., 1989. The replacement of cassava flour with groundnut cake in the nutrition of the African Snail (Archachatina marginata) (Swainson). M. Sc. Thesis, Department of Wildlife and Fisheries. University of Ibadan, Ibadan. (Unpublished).

Ogogo, A. U., 2002. Optimal stocking Densities and Utilization of two Snails, Archachatina marginata saturalis and Archachatina marginata ovum) Ph. D. Thesis, University of Ibadan, Ibadan (Unplished).

Ogogo, A. U., 2004. Wildlife Management in Nigeria. Objectives, Principles and Procedures. Calabar. Median Communications. Pp. $134-154$.

Omole, A. J., Taiwo, A. A. and Amusan, J. A., 2007. Technical Guide/Bulletin. Practical Snail Farming. Ibadan, Nigeria. Institute of Agricultural Research and Training, Moor Plantation.

Stivenant, C., 1996. Shell morphology, Growth, Reproduction and Aestivation by African Snails: laboratory observations on Archachatina marginata saturalis, Achatina achatina and Achatina fulica. Ph. D. Thesis. University of Ibadan, Ibadan (Unpublished) P. 206.

Ubua, J. A., 2004. Reproductive potentials of two snails - Archachatina marginataovum and Archachatina marginata saturalis in the Swamp Forest Zone of Nigeria. M. Sc. Thesis. Department of Animal Science, University of Calabar, Calabar. (Unpublished).

World Bank, 2001. World Development Report 2000/2001: Attacking Poverty. Oxford University Press, New York. P. 335. 